\title{
MUNICIPAL COASTAL GOVERNANCE SYSTEM DEVELOPMENTS IN LATVIA: GOVERNANCE SEGMENTS, SECTORS AND INSTRUMENTS
}

\author{
Raimonds Ernsteins ${ }^{1}$, Dr.habil.paed./Prof.; Erika Lagzdina ${ }^{2}$, M.Env.Sc., Ivars \\ Kudrenickis ${ }^{3}$, Dr.ing./Asoc.prof. and Anita Lontone-Ievina ${ }^{4}$, M.Env.Sc. \\ $1,2,3,4$ University of Latvia, Riga, Latvia
}

\begin{abstract}
Integrated coastal management (ICM) is still challenge at any governance level, but, particularly, for the small local governments and scattered coastal communities, especially, when aiming for in complementary manner of all stakeholders to design and create, establish and collaboratively manage the municipal coastal governance (MCG) system, but in practice having limited, often not linked, elements or instruments for such system as is also the case in Latvia. The EU BONUS programme, supported BaltCoast project (2015-2018) in the Baltic Sea region to provide related studies with an internationally acknowledged methodology based on socialecological system (SES) and stakeholder participation approaches - System Approach Framework (SAF), which was also adjusted for a particular local rural coastal governance process case in Latvia. Current study has been based on research-and-development (R\&D) framework, conducted in the typical local coastal municipality of Salacgriva as a pilot territory applying case study research (CSR) methodology (complementary stakeholder interviews, document studies, observations etc.). The aim of the study was to explore in to the detail the rural local coastal governance shortcomings, analysing all the triple complementary governance dimensions governance content, process and stakeholders' segments - and to recognize the main necessary preconditions for the local coastal governance process functioning and eventual governance system building elements. The findings of the research allow to propose also recommendations: for the local coastal governance process and system design in Latvian municipalities in general; for a range of approaches and basic pre-conditions to be taken into account - systems approach, complementarity and collaboration; also towards design and development of the mixed ICM application perspective for MCG. It was also recommended to develop MCG instruments, especially, coastal collaborative communication instruments - information, education, participation and coastal-friendly behaviour.
\end{abstract}

Key words: governance system design, preconditions, systems approach, complementarity, collaboration. JEL code: Q20, Q57, Q58

\section{Introduction}

Integrated coastal management (ICM) is based on aims and tasks integration of coastal environmental protection with those of coastal areas wise use of resources and local development facilitation. This requires development of related policies and regulations, administration and planning, involving other tools and, particularly, stakeholder participation, towards governance system development, to perform that integration and adaptive management of all multiple interests and practices of different development sectors at all levels of administration (GESAMP, 1996; Christie, 2005; Ballinger, 2008; Ernsteins, 2010; Quesada, 2018;). Stakeholder involvement is considered beneficial for gaining trust, knowledge, reducing conflicts, though there is present concern that the public may not be sufficiently well-motivated to participate (Evans et al., 2018; Schumacher et al., 2018; ). There is still a growing number of literature sources on how participatory processes can help adaptive management of socio-ecological systems (SES) such as coastal areas (Quesada et al., 2018; Schumacher et al., 2018; Wamsler, 2017); even coastal communities are not sufficiently informed and face difficulties in accessing-applying information (Stojanovic, 2007; Ballinger, 2008; Kalpakis et.al., 2019; Ernsteins, 2011; Lagzdina et al., 2017). System Analysis Framework (SAF) now is internationally recognized method for better ICM particularly building on social-ecological

\footnotetext{
${ }^{1}$ Raimonds Ernsteins e-mail: raimonds.ernsteins@lu.Iv

2 Raimonds Ernsteins e-mail: erika.lagzdina@lu.Iv

3 Ivars Kudrenickis e-mail: ivars.kudrenickis@lu.Iv

${ }^{4}$ Anita Lontone-Ievina e-mail: anita.Iontone-ievina@lu.Iv
} 
systems and public involvement for the whole project cycle (Ostrom, 2009; Hopkins, 2012). SAF methodology based on research and development (R\&D) project frame has been step-by-step implemented in a pilot coastal rural municipality in Latvia - Salacgriva municipality, forming a narrow stretch along $55 \mathrm{~km}$ of coastline (around $10 \%$ of the whole Latvia coast) with less as 9000 inhabitants. SAF was methodologically adapted for the need of the local level municipal coastal governance (MCG) process (Kudrenickis, 2016, Ernsteins, et al., 2017) during international project BaltCoast ("A Systems Approach Framework for Coastal Research and Management in the Baltic", 2015-2018) co-financed by the Latvia government and EU BONUS programme. R\&D project was aimed at studying limited coastal governance process in order to develop locally feasible tools for coastal resources and capacities for real governance development, using innovative approaches for Latvian MCG and existing variety of successful cases of both top-down and bottom-up general municipal management elements in Salacgriva community.

First stage of BaltCoast R\&D project studies done in rural coastal municipalities of Latvia (Lagzdina, 2017; Ernsteins, 2019; etc.) brought us again to the general conclusions (Ernsteins, 2010; etc.) that there still are to be seen: limited understanding and acknowledgement of the diverse and accumulating, even not yet crucial, coastal governance process problems; lacking known and statutory recognized vision and related efforts for sustainable use of the coastal resources and services, except for general interest towards standard beach tourism infrastructure; especially, main participatory and adaptive, cross-sectorial and cross-level deficiencies in ICM (Ernsteins, 2011 and 2017a). Also during this first stage there were identified the five overall key coastal governance process problems (Ernsteins, 2019), and second stage of this R\&D project continues with this study.

In Latvia, the initial developments of the overall national level coastal areas' spatial planning system were most welcomed as based now on Coastal Spatial Planning Strategy (2011-2017) and Coastal Public Infrastructure Development Plan (2016-2030), as first national coastal sectorial approach documents, being finally elaborated after long term strong pressure of science, municipal and public (NGO) stakeholder groups, and, also importantly, as some related steps towards general agreement and eventual implementation of EC Integrated Coastal Zone Management Recommendations (EC, 2002). At the same time, both mentioned national spatial planning documents and process around them, being multi-stakeholder supported (National Advisory Coastal Cooperation and Coordination Group) has been oriented almost only to the coastal public infrastructure planning, aimed at coastal tourism development, while also reducing its anthropological pressure. Even improvement and good coastal governance is recognized as the second coastal planning task, there is no strong requirement for integration of coastal issues and ICM principles (EC, 2002) into all statutory municipal planning documents, and the message perceived by municipalities is that coastal infrastructure is going to solve ICM issues. ICM is about creation and functioning of necessary governance systems (Ballinger, 2008; Ernsteins, 2011 and 2017a) that allow to integrate stakeholders' interests into the whole governance cycle participation process on full spectrum of coastal content issues (SES approach) to be managed by governance instruments (Ernsteins, 2017b).

\section{Research approaches, frames and models}

The whole R\&D project and, particularly, research part was a complex set of the consequential steps, carried out in the pilot territory of the Salacgriva local rural coastal municipality. The activities 
were based on SAF approach and the case study research (CSR) methodology utilizing complementary set of mutually to be integrated methods, including field works, which were conducted by the research team of the University of Latvia, Environmental Science Department, with involvement of Environmental Science master level students, after the necessary preparation steps during related study course (2015-2016). The aim of the study was to explore in the detail the rural local coastal governance shortcomings and existing positive experience as of one of most developed rural coastal municipalities in Latvia, analysing all the triple complementary governance dimensions' model - governance content, process and stakeholders' segments (Ernsteins et.al., 2017b) - and to recognize the necessary preconditions for the coastal governance system development. Ultimate aim for the CSR was also to establish interface between two methodologically defined processes: SAF, from one side, and the coastal and municipal development planning, from the other side, revealing new coastal municipal governance instruments and, particularly, drafting suggestions for governance system developments and coastal monitoring system, as well as later on preparing proposals for their integration into municipal planning. The Salacgriva coastal municipality was evaluated within the context of traditional complementarity of sustainable development (SD) dimensions and systemically integrated dimensional (methodological) sustainability model, focusing on nature environment (incl. coastal environment, risk environment, utility environment, and spatial environment), but within the broader perspective of the other SD elements - social, culture, economic, communication and governance, and spatial environments (Figure 1).

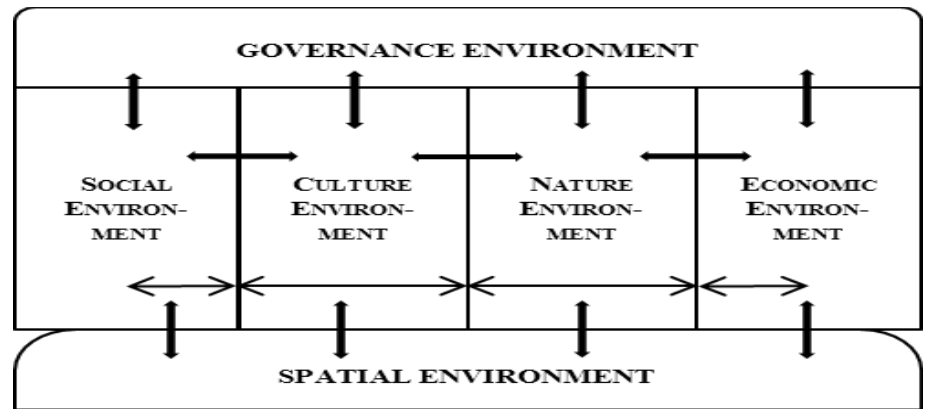

Fig. 1. Enhancement of the traditional triple bottom line sustainable development dimensions model into a six-dimensional frame for MCG content application (Ernsteins, 2010)

A complex and interlinked coastal governance content system for the needs of this research and perspective development of action policies recommendations was split into four main coastal governance content sectors: 1 . Coastal governance and communication; 2 . Coastal infrastructure environment (including coastal technical, spatial planning); 3. Coastal socio-economic environment; 4. Joint coastal nature and cultural heritage. It provided systemic basis for exploring sector-specific governance ideas and appropriate instruments and tools for all stakeholders (governance segments).

Coastal stakeholders structuring into the groups was based on complementary five governance segments model (Figure 2) that consists of (Ernsteins, 2010): state environmental/coastal institutions (esp. regional agencies); local municipal institutions (incl. administration, service and utility companies); 


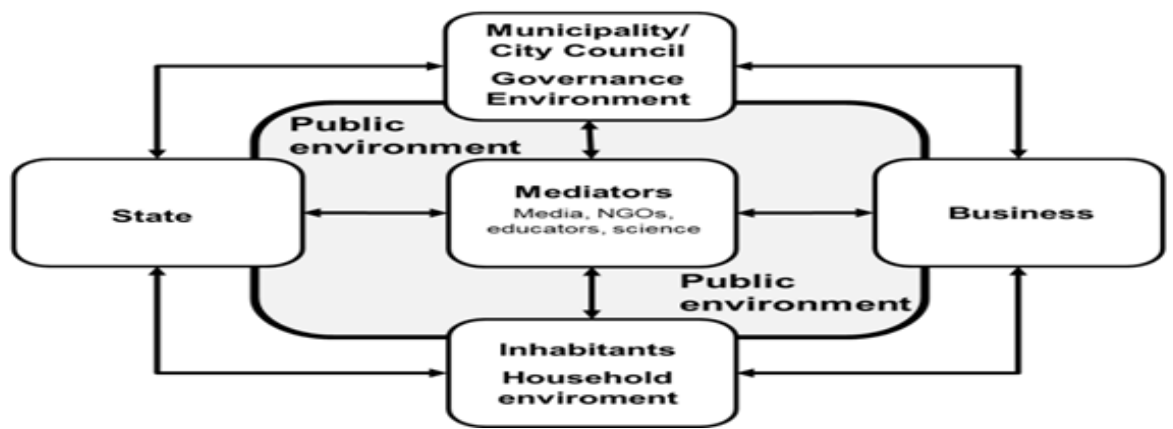

Fig. 2. Main (coastal) stakeholder segment's constellation (Ernsteins, 2010)

Salacgriva municipality located business companies; mediators segment (incl. non-governmental organizations (NGOs), villages' elders - community representatives; formal/ informal educators; media and various experts representing a science sector); and most significant stakeholder group was local inhabitants, analysed also from the coastal households' management perspective.

Subsequently, according to the development goal, the SD system approach, integration principle and complementarity of traditional governance instruments were used also further to elaborate coastal governance guidelines and testing compliance of their eventual implementation in the Salacgriva (and/or other) coastal municipality case. The coastal governance process shall be seen via all governance cycle steps - situation/problem analysis, policy design and formulation, policy planning, implementation/management and monitoring - but esp. looking for redesign/implementation of six main governance instruments' groups (Ernsteins, 2010) - political and legislative instruments, institutional and administrative, also planning instruments, as well as infrastructure and technological, economic and financial, also communication instruments (Figure 3 ). In general, for all coastal municipalities, MCG guidelines could be emphasizing the eventual coastal cross-sector governance planning document, both, as an eventually fully operational single/sectorial ICM (ICM sector approach) local statutory document and/or, at least, as a systembased structured pre-planning support document, providing a necessary content for coastal governance system issues to be integrated (ICM integration approach) into forthcoming municipal development statutory and also any voluntary planning processes and their produced documents.

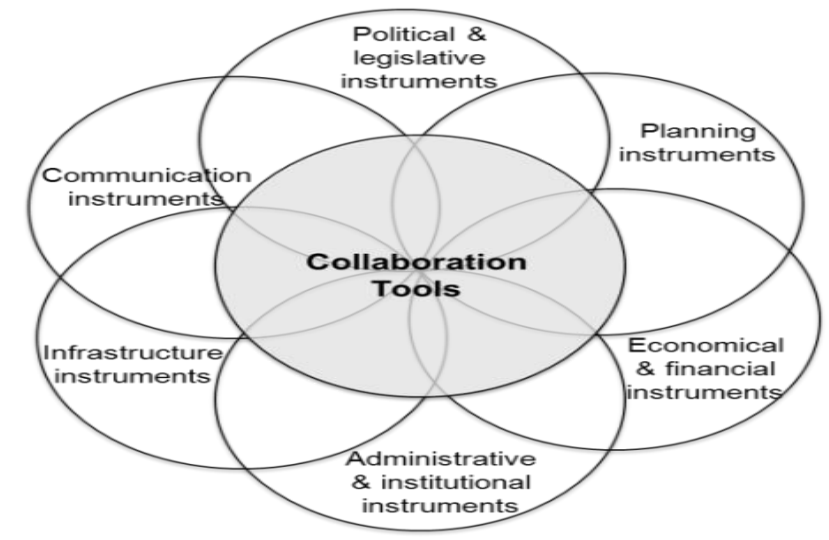

Fig. 3. Governance instrument groups and complementary option for development of collaboration instruments (Ernsteins, 2010)

\section{Case study research methodology and methods}

The following research methods and specialized approaches were applied for this CSR study.

1) Initially, during this stage of research, the re-analysis of ICM elements' presence was done (2015) together with the whole international consortium of the BaltCoast project (Jansen et al., 2016) by revisiting a number of methodologically profoundly selected cases of the ICM practices 
taken place during last decade and around the whole Baltic Sea. This was realized by addressing the complex coastal problem-situations in order to study the best formerly used ICM approaches, principles and tools applications via the SAF methodology (Re-analysis was intended to serve as a preparatory step before a full scale application of SAF in the BaltCoast project's pilot sites, incl. Latvia (Lagzdina et.al., 2017a; 2017b). Re-analysis included three Latvian cases (two represent the port cities and one - a rural community) which were selected as the still most complete experience demonstrating application of the ICM principles in the municipal coastal management (Ernsteins et. al., 2017a). These cases were: 1) Setting-up of a voluntary municipal environmental licensing system in Ventspils town (1994-2009); 2) Bottom-up self-organized process for protection of the Pavilosta Grey Dune (1999-2007); and 3) Development of a voluntary spatial planning instrument in the Liepaja city -Thematic plan of coastal zone development (2014-2015).

2) All further steps of this research stage contributed to the analysis of MCG in Salacgriva municipality concerning MCG segments, process and content analysis sought for the integration assessment and first step to be mentioned was performed - MCG issues in the municipal development planning and legal documents. For this purpose, content analysis of 23 national and local level policy documents and regulations was done. It was complemented also by the analysis of information from 13 available municipal and regional data bases covering issues of local development and environment.

3) To fulfil SAF requirement for stakeholder involvement, initial mapping of stakeholders was done. Essential step was done already during first research stage (Ernsteins et. al., 2019) as a survey (2015) of the representatives from all key stakeholder groups, living directly at the coastal strip along the municipal coastline (stretching for all the $55 \mathrm{~km}$ along the Baltic Sea Riga Gulf East coast). Interactive involvement of stakeholders was ensured during different stages of the R\&D project and in different formats - for this second research stage (2015-2016) it was an introductory seminar with municipal leaders and specialists; during implementation phase activities; and presentation of the results and final stage discussion in the seminar for representatives from the municipality.

4) Semi-structured in-depth interviews (2015) were conducted with 39 stakeholders representing all main governance segments as described above and revealed in Fig. 1. Particular and detailed list of interviewees is presented in the next table (Table 1). Content of the interviews was based on the mentioned triple complementary coastal governance dimensions - governance content, process (incl. all six main groups of governance instruments) and stakeholders' segments (Ernsteins et.al., 2017b).

Application of the classic planning method SWOT analysis revealed the strength and opportunities, weaknesses and threats of the coastal governance, and, thus finalizing problem-analysis stage of coastal governance cycle and suggesting necessary frame for next stages of policy design, formulation and policy planning, its implementation and management, monitoring (Ernsteins et. al., 2017b). 
In-depth interviews: coastal local stakeholder segments and representatives

\begin{tabular}{|c|c|}
\hline $\begin{array}{l}\text { Stakeholder } \\
\text { segment }\end{array}$ & $\begin{array}{l}\text { Representatives in Salacgriva municipality } \\
\text { (institution/unit or position and number of interviewed people) }\end{array}$ \\
\hline $\begin{array}{l}\text { State/national } \\
\text { segment }\end{array}$ & $\begin{array}{l}\text { Nature Protection Agency (NPA) regional unit; state environmental inspector; } \\
\text { public relations and environmental education unit - information specialist }\end{array}$ \\
\hline Municipal segment & $\begin{array}{l}\text { Political level/administration: Chair of the Municipal Council; council members } \\
\text { (4) } \\
\text { Consultative bodies: Business Consultative Board (1); Youth Consultative Board } \\
\text { (1) } \\
\text { Executive level: Executive director of municipality; Deputy executive director on } \\
\text { development; Head of finance unit; Head of Information Unit; Human resources } \\
\text { specialist; Municipal education unit specialist; Buildings and territory manager; } \\
\text { Energy engineer; Construction supervisor; Policemen (2) } \\
\text { Municipality-owned utility service: Salacgriva Water Service (2) }\end{array}$ \\
\hline Business segment & $\begin{array}{l}\text { Port services (1); Fishery industry (2); Small tourism (3); and Small } \\
\text { entrepreneurs/farmers ( } 2 \text { ) }\end{array}$ \\
\hline Mediators' segment & $\begin{array}{l}\text { NGOs: Pensioner society; Fishermen society; North Vidzeme Biosphere } \\
\text { Reserve's society; coastal NGO Jurkante (the only one environmental NGO); Ex- } \\
\text { elder of the Svetciems village; } \\
\text { Media: Salacgriva Municipality News } \\
\text { Formal education sector: Local secondary schools' directors (2) } \\
\text { Informal education sector: Tourism information centre head/staff (2); Head of } \\
\text { Salacgriva museum; Head of local Youth Centre; Culture group: folklore group }\end{array}$ \\
\hline $\begin{array}{l}\text { Inhabitants/household } \\
\text { segment }\end{array}$ & $\begin{array}{l}\text { Represented in this survey in personal capacity of those local specialists } \\
\text { mentioned in above segments (see also previous research stage study results } \\
\text { (Ernsteins, 2019)) }\end{array}$ \\
\hline
\end{tabular}

\section{Research results and discussion}

\section{Re-analysis: complementarity of coastal communication instruments}

Complete results of the re-analysis of three former ICM studies in Latvia and in different coastal municipalities as Salacgriva are discussed in the other publications (Ernsteins et al., 2017a; Jansen et al., 2016). The results demonstrate that SAF elements as regards applying multi-disciplinary perspective to the coastal SES assessment and issue identification and general involvement of local stakeholders in ICM processes were present in all three Latvian cases, though in different qualities. Yet, a key to overall governance success has been dependent on the comprehensiveness of public participation, which in the Latvian cases has exceeded traditional participatory methods. This demonstrates the need for strengthening public/citizen component and communication tools for the ICM application.

Latvian cases demonstrate consistent use of all environmental communication instruments in ICM: environmental information, environmental education, public participation in decision-making, and what is essential, to complete communication and awareness building cycle, also pro-environmental behaviour, which all together make a set of complementary coastal communication instruments, that is recognized as key pre-requisite for adequate ICM process management (Ernsteins, 2010). Further work brought us to the conclusion that for addressing deficiencies in ICM, it is necessary to develop coastal collaborative communication, which builds on involvement of all stakeholder groups; on related coastal topics selectively, multi-thematically oriented and based on complementarity of all communication instruments. It was also recommended to develop MCG instruments, especially, coastal collaborative communication instruments, which are based on involvement of all stakeholder groups and on related coastal topics selectively, being multi-thematically oriented and based on complementary use of all communication instruments. 


\section{Municipal statutory planning documents: integration of the coastal issues}

Every administrative planning level (national, regional, local/municipal) is requested to have besides budget also three interlinked statutory planning documents - strategic and mid-term policy planning, mid-term spatial planning - as well as permission to develop various voluntary thematic planning documents. There is no interest to develop coastal issues related thematic planning documents in Salacgriva municipality. At the regional planning level there is planning document on coastal nature tourism development for eastern coast of the Baltic Sea Riga Bay.

The most comprehensive local long-term document is a Sustainable Development Strategy until 2038 (SDS). It was co-developed with the group from the University of Latvia in 2014. Still, the coast and its resources, as well as the Baltic Sea and the Riga Sea Gulf, are incompletely reflected in the territory's description. Long-term development vision of the municipality is distantly related to the coastal specifics, namely, it is envisaged to ensure adaptation to climate change and to maintain characteristic coastal cultural landscape. Though, the vision is not transformed in the coast-specific goals, however, strategic priorities envisage use of coastal resources and specific features for entrepreneurship, especially port services and recreation (yachts), fishing and fishery production. From spatial development perspective, the coast is recognized in SDS as one of priority territories where infrastructure, environmentally friendly moving (biking road) and river management issues shall be managed. The coast has significant functional role. It is emphasized that the coast is freely accessible. It is local, national, and international tourism destination, economic transit point, recreational transport point, while it is also suffering from environmental pollution and socioeconomic interests causing pressures.

Salacgriva Municipality Development Program 2015-2021 (DP) does not sufficiently conceptualize coastal perspective for development. Generally, DP fails to reflect specificity of the coastal municipality and consequent coast-related challenges or does it poorly. Coastal issues are scattered in the text. As a result, there is no analytical understanding of coastal potential and its contribution to the local socio-ecological system (incl. economy). As the DP envisages implementation evaluation, for 11 mid-term priorities set in this DP, 39 resultative parameters (indicators) are selected to measure progress. But only five of them are related to the coast: two are linked to the ports' activities, three - to the access to the sea and related infrastructure, and one - to the quality of bathing waters. Though there are not quantitative values suggested, only direction of positive tendency is referred to. Indispensable part of the development documentation is Action Plan (AP) and Investment Plan, which contain activities related to the implementation of the following coastspecific priorities: extension of port services; improvement of coastal infrastructure for tourism and recreational purposes; ensuring better and more controlled access to the sea; reconstruction of two quaysides, old lighthouse with great historical value and floods management.

Spatial Plan (SP) uses zoning instrument and specifies so called General Regulations for Territory Use and Building. It maps out territories on the coast for recreation and tourism, access points to the sea, bathing sites, nature territories etc. Analysis shows that at all spatial planning levels, coastal protected belts, and towpaths, as well as restrictions are stipulated by national legal acts, mainly Protection Zone Law (adopted 1997, with amendments in 2016) and Law on Specially Protected Nature Territories (1993, with amendments in 2013). Accordingly, specific requirements are defined in the $5 \mathrm{~km}$ width of the coastal zone where restrictions of economic activities are enforced as regards construction, extraction of minerals (what is strictly forbidden in the coastal dunes and specially protected landscape territory of the North Vidzeme Biosphere Reserve, and the Stony Shore of the 
Vidzeme, which belong to the Natura2000 sites). SP defines, that access to the sea/coast shall not be limited with private constructions. Zoning tool also regulates the use of beach (e.g. limits use of motorized water transport).

\section{Stakeholders' mapping and survey: stakeholders' roles in the coastal governance}

As it results from stakeholder survey, the national level (state sector) presence is defined by location of the municipality in the territory of the North Vidzeme Biosphere Reserve (NVBR) that is managed by the Nature Protection Agency (NPA), which is subordinated to the Ministry of Environment and Regional Development of Latvia. Nature protection regime to large extent stipulates requirements and restrictions for economic activities, which embodies potential for conflicts in the territory. Thus, cooperation with the regional office of the NPA is a precondition for collaborative coastal management. Besides controlling and licencing tasks, the NPA is active in nature education and tourism. Its experience in setting up a public monitoring network in the territory is unique as a novel public involvement tool.

Local municipality is a complex institution with different levels of responsibilities as regards the coastal management, that are split among political, administrative, and public service (utility) powers. Municipal management responsibilities are diverse: starting from provision of cleanness and safety of the beach to floods management, licencing (fishing rights etc.), supervising construction, initiating projects, attracting financing, and providing infrastructure for public services, as well as business, transport and tourism activities. In this context, the role of local Business Consultative Board as a participatory tool is essential for enhancing coastal collaboration between entrepreneurs and administration. Significance of the Baltic Sea and marine resources, as well as transport opportunities is essential for business activities in the territory. Besides, the coastal resources are used as a key asset for tourism enterprises.

Mediators' sector is diverse and well developed. There are numerous culture groups acting in the local culture centres. Five museums and Tourism information centre play a significant role in informing on and maintaining of unified coastal nature-culture-history heritage. Libraries act as local activity and informal/life-long education centres. Local schools integrate environmental education in school curricula and take part in national and global Eco-school movement and environmental campaigns on the coast. In scope of local non-governmental sector, the most active are pensioner and fishermen societies. But there is only one NGO working with the coastal issues. The municipality has several participatory institutions (different advisory councils) that play significant role in local collaboration and information exchange. The most significant among them is the Village Elders institution that ensures information exchange between central administration and citizens. At the same time, interviews revealed that coast specifics in the activities of local stakeholder groups is marginal. Missing understanding of the coast could be seen as generalization of the stakeholder perceptions. Stakeholders' awareness about the coast is usually limited to their proximity ('my village'), or to the land strip between the highway and the sea.

\section{SWOT analysis of coastal governance for planning framework suggestions}

Stakeholders' interviews and other in-depth MCG as sector governance studies revealed strength and opportunities, weaknesses and threats of the MCG components in the Salacgriva municipality, which are summarized in the SWOT table (Table 2). This analysis allowed to identify essential sectors 
and work directions to ensure sustainable and integrated management of all coastal sustainability dimensions.

\section{SWOT analysis: Coastal governance aspects in the Salacgriva municipality}

\begin{tabular}{|c|c|}
\hline Strength & Threats \\
\hline 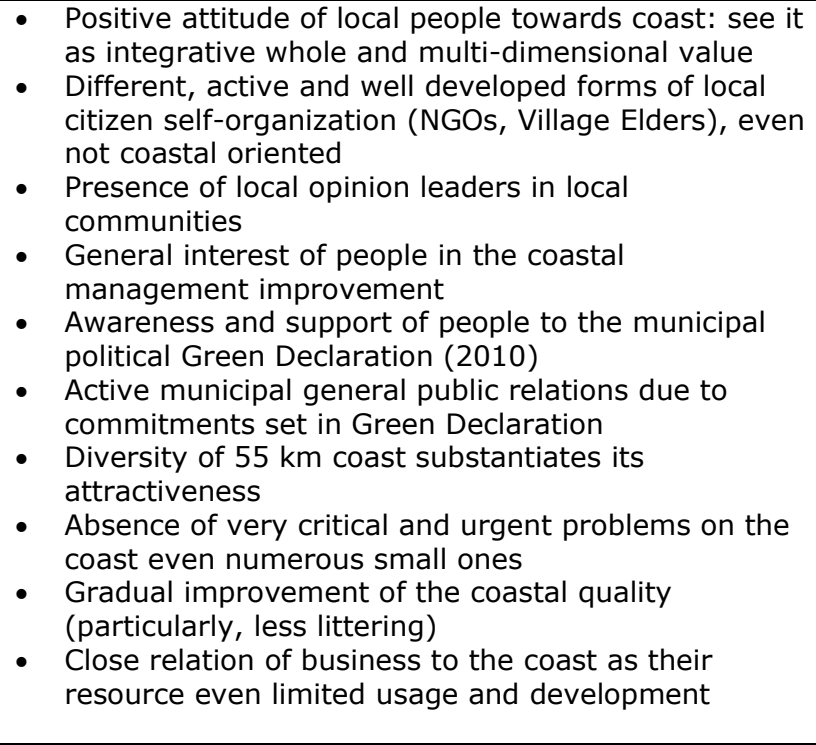 & $\begin{array}{l}\text { - Tourism flow reduction due to low quality of } \\
\text { coast (during algae blooming season; after } \\
\text { storms, due to invasive plants) } \\
\text { - Increased unregulated flow of visitors to the } \\
\text { coastal zone } \\
\text { - Visitors behaviour degrades valuable biotopes, } \\
\text { which accelerates due to lack of management } \\
\text { - Increased coastal littering after holidays- } \\
\text { seasonal pressures } \\
\text { - Transboundary pollution pressures deteriorate } \\
\text { bathing waters quality } \\
\text { - Impacts of climate change becomes more } \\
\text { - } \text { covere and frequent (storms, floods, heat) } \\
\text { - Leteriorating coastal quality } \\
\text { - camited fish stocks and invasive species } \\
\text { activities } \\
\text { Restrictions for economic activities and } \\
\text { construction in the coastal zone of } 5 \mathrm{~km} \text { and } \\
\text { esp. in } 150 m \text { (300m outside villages) zone by } \\
\text { the national regulation }\end{array}$ \\
\hline
\end{tabular}

\begin{tabular}{|l|}
\hline \multicolumn{1}{|c|}{ Weaknesses } \\
\hline -
\end{tabular}
a resource itself also due to strong national coastal zone legislation/enforcement tradition

- Coastal bio-geodiversity and accessibility impedes management

- Lack of sufficient coastal infrastructure - proenvironmental coast access problems in the most of territory

- New access limitations appear due to growing territory of invasive coastal plants (e.g. roses)

- Fragmentation of coastal problems and lack of their topicality in eyes of different stakeholder

- Irresponsible behaviour of local people (and relatedly guests) in coastal zone/dunes causing its littering and esp. degradation

- Shortcomings in municipal coastal governance: lack of human resources and their capacity; passive management practice, lack of coastal issues integration into planning documents

- Insufficient citizen awareness and trust, e.g. participation, in admin and planning process

- Limited, even many and diverse, local NGOs interest on coast

- Limited public monitoring (e.g. Citizen science) interest and practice from top-down and bottom-up sides, even existent and successful former practice by Biosphere Reservation admin with local school etc. collaboration

- Stakeholders are adhered to projects as a tool for attracting financing rather as tool for the coastal problem solving

- Narrow spatial perception of the coast and its situation by inhabitants/NGOs

- Limited rights for bottom-up selected Village Elders

- Week stakeholders' interest in joint solutions collaboration

\section{Opportunities}

- Coastal attendance improvement while limiting pressures on ecosystem by Improved infrastructure and services

- Coastal science knowledge use for developments for coastal use based zoning and general planning

- Presence of Biosphere Reservation administration in the territory, e.g. Environmental education centre

- Information platforms and media activation in coastal information dissemination

- Disperse pollution loads reducing by environmentally sound business activities (eco-farming etc.)

- Lobbying for national legislation and regional enforcement on wise restrictions in the coastal zone

- Provision of prototypes/standardized models for small-scale coastal infrastructure (already approved by the state environmental institutions)

- Growing coastal recognition/support by Riga Planning Region (regional institutional municipal partnership) and

- Inter-municipal planning and partnerships, incl. Union of Coastal municipalities

- Activation of Ministerial level admin and planning works on coastal issues, e.g. new National Coastal public infrastructure policy document (2016) to be implemented towards local coastal municipalities, incl. necessary implementation support, incl. financial mechanisms etc. whole range of governance instruments

- Further use of EU accepted approach for this planning period for coastal infrastructure funds as well as national environmental funding recent availability on coastal issues 


\section{R\&D discussion: MCG content framework Guidelines}

Understanding and management of the coastal resources in integrated manner, taking into account all sustainability dimensions, since approaching coastal governance as social-ecological system (SES) governance, is still a theoretical and practical challenge for municipal level everyday practice. According to the former studies and the above methodological frame and approaches (Ernsteins et.al. 2016), studies lead to the conclusions, that there are the following four MCG content sectors selected: Coastal governance and communication; Coastal infrastructure; Coastal socioeconomic environment, and Joint coastal nature and cultural heritage (Table 3). For them, 10 directions of main action frame and also detailed sub-directions were proposed. These elements of governance system are suggested by the research team as a basis for structure of more detailed further studies and/or for planning of coastal activities. In fact, this forms a potential basis to be developed as the Salacgriva MCG Program Framework Guidelines.

Table 3

\section{Municipal Coastal Governance Program Framework Guidelines: integrated sectors and related main work directions based on governance content 4-dimensional model (Authors, 2015)}

\begin{tabular}{|c|c|c|}
\hline $\begin{array}{l}\text { Govern. } \\
\text { sectors }\end{array}$ & Directions of action & Sub-directions of action \\
\hline \multirow[b]{2}{*}{$\begin{array}{l}\text { 1. Coastal } \\
\text { governance and } \\
\text { communication } \\
\text { environment }\end{array}$} & $\begin{array}{l}\text { 1.1. Governance } \\
\text { environment }\end{array}$ & $\begin{array}{ll}\text { 1.1.1. } & \text { Top-down governance } \\
\text { 1.1.2. } & \text { Bottom-up governance }\end{array}$ \\
\hline & $\begin{array}{l}\text { 1.2.Communi-cation } \\
\text { environment }\end{array}$ & $\begin{array}{l}\text { 1.1.3. Coastal integrated governance (in general) and climate change adaptation and risk } \\
\text { governance (in particular) } \\
\text { 1.2.1. Access to environmental/coastal information } \\
\text { 1.2.2. Environmental/coastal education - formal, informal, life-long learning } \\
\text { 1.2.3. Environmental/coastal participation - public involvement and self- } \\
\quad \text { initiatives; stakeholder cooperation } \\
\text { 1.2.4. Pro-environmental/pro-sustainable coastal behaviour (PEB) }\end{array}$ \\
\hline \multirow{3}{*}{$\begin{array}{l}\text { 2. Coastal } \\
\text { infrastructure } \\
\text { environment } \\
\text { (including spatial } \\
\text { planning) }\end{array}$} & $\begin{array}{l}\text { 2.1.Technical } \\
\text { environment (utilities) }\end{array}$ & $\begin{array}{l}\text { 2.1.1. Water supply and sanitation compliance for all } \\
\text { 2.1.2. Wastewater treatment and environmentally sound management of } \\
\text { sewage sludge } \\
\text { 2.1.3. Household waste management } \\
\text { 2.1.4. Heating and air quality }\end{array}$ \\
\hline & $\begin{array}{l}\text { 2.2.Spatial } \\
\text { environment }\end{array}$ & $\begin{array}{l}\text { 2.2.1. Land management } \\
\text { 2.2.2. Integrated in environment public outdoor space } \\
\text { 2.2.3. Climate change adaptation and risk governance } \\
\text { 2.2.4. Built environment (incl. Coastal Building Guidelines) }\end{array}$ \\
\hline & $\begin{array}{l}\text { 2.3. Infrastructure } \\
\text { environment }\end{array}$ & $\begin{array}{l}\text { 2.3.1. Amelioration and non-depleting access to environment (for all- } \\
\text { inhabitants, tourists, fishermen, boatmen, recreational business) } \\
\text { and infrastructure enabling tourism/recreation, nature protection } \\
\text { 2.3.2. Sanitary infrastructure - toilets, waste bins } \\
\text { 2.3.3. Climate change adaptation and risk governance: safe public } \\
\text { environment and infrastructure } \\
\text { 2.3.4. Complete information infrastructure contacts of nature guides, } \\
\text { municipal services, destinations/directions }\end{array}$ \\
\hline \multirow[t]{2}{*}{$\begin{array}{l}\text { 3. Coastal socio- } \\
\text { economic } \\
\text { environment }\end{array}$} & $\begin{array}{l}\text { 3.1. Sustainable living } \\
\text { environment }\end{array}$ & $\begin{array}{l}\text { 3.1.1. Social services } \\
\text { 3.1.2. Education - support system for locally required skills/professions: } \\
\text { support for those studying outside, education for locals, life-long } \\
\text { education, distance work options } \\
\text { 3.1.3. Environmentally friendly housing } \\
\text { 3.1.4. Pro-environmental mobility } \\
\text { 3.1.5. Environmentally and health friendly food (incl. seafood; local market) } \\
\text { 3.1.6. Pro-environmental behaviour in public space/environment } \\
\text { 3.1.7. Development of local communities }\end{array}$ \\
\hline & $\begin{array}{l}\text { 3.2. Environmentally } \\
\text { friendly business }\end{array}$ & $\begin{array}{l}\text { 3.2.1. The countryside, sea, forests, tourism - connections with } \\
\text { ecosystems and their conservation, capacity } \\
\text { 3.2.2. Real estate management - as business opportunity } \\
\text { 3.2.3. Tourism and ecotourism (accommodation and catering, networking) }\end{array}$ \\
\hline \multirow[t]{2}{*}{$\begin{array}{l}\text { 4. Joint coastal } \\
\text { nature and culture } \\
\text { environment }\end{array}$} & $\begin{array}{l}\text { 4.1.Nature } \\
\text { environment }\end{array}$ & $\begin{array}{l}\text { 4.1.1. Nature and landscape values/assets serving for creation of } \\
\text { protected nature territories } \\
\text { 4.1.2. Management of biologically important meadows, forests etc } \\
\text { 4.1.3. Surface waters and fish resource governance } \\
\text { 4.1.4. Migration of birds and animals }\end{array}$ \\
\hline & $\begin{array}{l}\text { 4.2.Culture } \\
\text { environment }\end{array}$ & $\begin{array}{l}\text { 4.2.1. Coastal material and non-material values } \\
\text { 4.2.2. Effective use and governance cultural-historical heritage }\end{array}$ \\
\hline
\end{tabular}




\begin{tabular}{|l|l|l|}
\hline & & 4.3.1. Basis for coastal development - unity of natural and cultural values \\
& 4.3.Joint coastal & 4.3.2. Material heritage: home production, crafts \\
& heritage & 4.3.3. Intangible heritage (traditional festivals, events) \\
& & 4.3.4. Cultural-historical monuments \\
&
\end{tabular}

\section{Conclusions and recommendations}

1) R\&D study done in coastal rural municipality of Salacgriva exploring existing coastal governance process problemsituation have been leading to more detailed understanding and following confirmation of succesfull applicability of all triple complementary governance dimensions model, both as the methodological governance research frame and as the eventual framework for municipal coastal governance system design and development, subsequently, being based on governance content, governance process and governance stakeholders' segments.

2) Main stakeholders and coastal governance segments. Interviews with representatives of all main municipal stakeholder groups, complemented by studies of municipal documents, data resourses and locallly designed projects, allowed to recognize stakeholders' limited understanding of the coast as complex socio-ecological system, week acknowledgement of the coastal problems and a lack of vision for sustainable use of the coastal resources, subsequently, their limited contribution to MCG.

3) Coastal governance content. Existing statutory and other planning and management documents do not fully represent neither coastal issues/resources, nor conceptualize coastal system development, e.g. failing to reflect specificity and perspective of the coastal municipality. Relatedly developed recomendations as MCG Program Framework Guidelines proposes SES governance approach, based on systemically integrated costal governance content 4-dimensional model, which could be recognized as pre-requisite for adequate MCG process planning and management.

4) Coastal governance process and instruments. Wide range of existant general municipal development governance instruments are neither necessarily complementary nor does fully cover MCG issues. Recomendations include accordingly to replan/restructure all set of six main instrument groups and establish several MCG sector instruments, e.g. MCG monitoring and reporting. Coastal collaborative communication shall be based on complementarity of application of all four main groups of communication instruments.

5) Application of mentioned governance research frame, but studying separately each of three governance dimensions are permitting to figure out and to make initial confirmation (also in the relation to the former studies done) on the three basic pre-conditions for the MCG process functioning and building elements for eventual MCG system: systems approach, complementarity and collaboration, however their further detailed studies have been planned for the next stage of BaltCoast project.

\section{Acknowledgement}

R\&D study done within the framework of the BaltCoast project with financial support of EU BONUS program and Latvian national co-funding. Authors would like to acknowledge all researchers and students being involved in this study, particularly, Ugis Rusmanis and Krista Osniece for studies administration. 


\section{Bibliography}

1. Ballinger, R, Cummins, V., O'Hagan, A.M., Philippe, M. (2008). The Point of COREPOINT: Improving Capacity for Integrated Coastal Zone Management in North West Europe. COREPOINT Report. p. 81.

2. Christie, P. (2005). Is Integrated Coastal Management Sustainable? Ocean Management, Vol.48, pp.208-232.

3. Cohn, J.P. (2018). Citizen Science: Can Volunteers Do Real Research? BioScience, Vol. 58, Issue 3, pp. $192-$ 197.

4. Coastal Spatial Development Guidelines for 2011-2017. Cabinet of Ministers 20.04.2011 Decision Nr. 169. Retrieved: http://polsis.mk.gov.lv/documents/3634

5. Conrad, C.C., Hilchey, K.G. (2011). A Review of Citizen Science and Community-Based Environmental Monitoring: Issues and Opportunities. Environ Monit Assess Nr.176, pp. 273-291.

6. GESAMP (1996). The Contributions of Science to Coastal Zone Management. Rep. Stud. GESAMP, IMO/FAO/UNESCO-IOC/WMO/WHO/IAEA/UN/UNEP Joint Group of Experts on Marine Environmental Protection. Nr.61, 66 p.

7. Quesada, C.G., Klenke, G.T., and Mejia-Ortiz, L.M. (2018). Regulatory Challenges in Realizing Integrated Coastal Management - Lessons from Germany, Costa Rica, Mexico and South Africa, Sustainability, No. 10, p.3772.

8. Ernsteins, R. (2010). Sustainable Coastal Development and Management: Collaboration Communication and Governance, Journal of Social Sciences, No.3, pp.247-252.

9. Ernsteins, R., Kaulins, J. et al. (2011). Integrated Coastal Management for Local Municipalities in Latvia: Sustainability Governance and Indicator system. WIT Transactions on Ecology and Environment, Vol. 149, pp.29-40.

10. Ernsteins, R., Lontone-Ievina, A. et al. (2017b). Integrated Coastal Management Practice Case Studies: Deficiency of Collaboration and Socio-Ecological System Approaches. Book Series: Economic Science for Rural Development. Issue 45, pp. 63-70.

11. Evans, S.M., Gebbels, S. (2018). Our Shared Responsibility: Participation in Ecological Projects - Means of Empowering Communities to Contribute to Coastal Management Process, Marine Pollution Bulletin, 57, pp.37.

12. Hopkins, S., Bailly D. et al. (2012). A Systems Approach Framework for the Transition to Sustainable Development: Potential Value Based on Coastal Experiments, Ecology and Society, Vol. 17, Issue 3, p.39. Hyder, K., Wright, S. et al. (2017). The Role of Citizen Science in Monitoring Small-Scale Pollution Events, Marine Pollution Bulletin, Vol. 120, Issues 1-2, pp. 51-57.

13.Jansen, H., Ernsteins, R. et al. (2016). A Retrospective Analysis of Best Practice Integrated Coastal Management Cases Around the Baltic Sea. In: European Coastal Lagoons Symposium. Abstracts Book. Marcos C., Perez-Ruzafa A., Perez-Marcos M., (eds.), Compobell, Murcia: pp. 212.

14. Kalpakis, V., Kokkos, N. et.al. (2019). An Integrated Coastal Zone Observatory at Municipal Level: The Case of Kavala Municipality, NE Greece, Journal of Coastal Conservation, Vol. 23, pp.149-162.

15. Karpouzoglou, T., Dewulf, A. and Clark, J. (2016). Advancing Adaptive Governance of Social Ecological Systems through Theoretical Multiplicity, Environmental Science \& Policy, Vol. 57, pp.1-9.

16. Kudrenickis, I., Ernsteins, R., and Kaulins, J. (2016). Sustainable Coastal Science-Policy Interface Development: Municipal Governance Indicator System, Environmental Science, No. 1, pp.255-264.

17. Lagzdina, E., Kudrenickis, I. et.al. (2017). Coastal Sustainable Development Studies in Latvia: Integrated Local Social-Ecological Systems Governance, Regional Formation and Development Studies, Vol. 1, Issue 21, pp.83-96.

18. Ostrom, E. (2009). Framework for Sustainability of Social-Ecological Systems, Science, No. 325, pp. 419-422.

19. Recommendation of the European Parliament and of the Council of 30 May 2002 Concerning the Implementation of Integrated Coastal Zone Management in Europe. OJ L 148, 6.6.2002, p. 24-27.

20. Ringsmuth, A., Lade, S., and Schluter, M. (2019). Cross-Scale Cooperation Enables Sustainable Use of a Common-Pool Resource.

21.Schumacher, J., Schernewski, G. et al. (2018). Methodologies to Support Coastal Management - A Stakeholder Preference and Planning Tool and Its Application, Marine Policy, Vol. 94, pp.150-157.

22. State Long-Term Thematic Plan for Development of Public Infrastructure on the Baltic Sea Coast. Cabinet of Ministers 17.11.2016 Decision Nr. 692.

23. Stojanovic, T.A. (2007) Guidelines for Implementing Local Information Systems at the Coast. COREPOINT and Cardiff University, Cardiff. p. 35.

24. Wamsler, C. (2017). Stakeholder involvement in Strategic Adaptation Planning: Transdisciplinarity and Coproduction at Stake? Environmental Science and Policy, Issue 75, pp.148-157 